Ks. Jan W. ŻELAZNY

(Kraków, UPJPII)

\title{
STAROŚĆ W STAROŻYTNEJ LITERATURZE ORMIAŃSKIEJ
}

Na wstępie kilka słów wyjaśnienia: na prośbę ks. prof. dr hab. Stanisława Longosza podjąłem się przygotować opracowanie dotyczące starości w starożytnej literaturze ormiańskiej. Znający mnie wiedza, że nie jest to ta część patrystycznej spuścizny, którą bym się zajmował wcześniej. Czas nie pozwala mi na dogłębne studium, choć sama literatura ormiańska w dużym stopniu przez wiele lat pozostawała pod wpływem interesujacej mnie spuścizny syryjskiej. Podstawą mojego wystapienia jest artykuł Marco Baisa ${ }^{1}$ o starości w literaturze ormiańskiej, opublikowany w pracy zbiorowej: Senectus. La vecchiaia nell'antichità w Bolonii. Nie będę jednak oceniał, na ile zawarte w nim tezy są reprezentatywne, na ile ich autor miał rację skupiając się na tych, a nie innych elementach. Dlatego też jako zasadę przyjąłem, by wybrać te elementy jego opracowania, które moim zdaniem są oryginalne w spuściźnie ormiańskiej. Nie odważyłem się mówić o cechach typowych, czy też stałych toposach literackich, bo ich po prostu nie znam, a nieuczciwością intelektualną byłoby cytować inne niż własne badania. Przedstawione jednak w wyżej wspomnianym artykule dane wskazały dwa elementy osądu i oceny starości, jakie wnosi tradycja ormiańska, a które wydają się być czymś zasługującym na uwagę.

Pierwszy z nich związany jest z oceną spotykanego w starożytnej literaturze armeńskiej wyrażenia, tzw. ,gadania starszych kobiet”, a raczej „,starych”. Zdaniem M. Baisa ${ }^{2}$, w literaturze armeńskiej nie ma za wiele tekstów, które pozwalałyby na pełne opracowanie roli i pozycji kobiet, a w szczególności kobiet starszych ${ }^{3}$. W analizowanych przez niego tekstach, w większości kronikach, nie ma osobnych passusów poświęconych temu zagadnieniu. Dla znającego kulturę Bliskiego i Środkowego Wschodu i to jeszcze w starożytności,

${ }^{1}$ Por. M. Bais, La vecchiaia nella letteratura armena antica, w: Senectus. La vecchiaia nell'antichità, ed. U. Mattioli, vol 3: Ebraismo e cristianesimo, Bologna 2007, 706-746: M. Bais, La concezione della vecchiaia nei testi armeni dei secoli V-VII, w: Pensiero e istituzioni del mondo classico nelle culture del Vicino Oriente. Atti del Seminario Nazionale di studio Brescia, 14-16 X 1999), ed. R.B. Finazzi - A. Valvo, Alessandria 2001, 55-78.

${ }^{2}$ Por. M. Bais, La vecchiaia nella letteratura armena antica, s. 706-746 (La donna anziana).

${ }^{3}$ Por. także teksty: Eliseus Vardapetus, Historia Vardani VI 124; Agathangelos, Historia Armeniae 35; Lazarus Parpecinus, Historia Armeniae I 13, 21; II 27, 50. 
zjawisko to nie budzi zdziwienia. Polityka i historia to nie są sprawy, w które angażowały się wówczas w sposób widoczny kobiety. Ówczesny topos literacki kazał w nich widzieć głównie zagrożenie i źródło zła, a pojawiające się wzmianki nie wykraczaja poza stereotypowe sformułowania. Jeśli kobieta była dobrą bohaterką, to była żoną i matką wierną swemu mężowi, nie narzucającą swego zdania. W takim wypadku nie było o czym pisać. Jeśli odegrała złą rolę, to wiadomo dlatego, że się zaangażowała w sprawy nie dla kobiet. Takie przekonanie powodowało, że trudno doszukać się w starożytnej literaturze ormiańskiej sylwetek kobiet wychodzących poza stereotypowy opis.

Tym niemniej, w kilku wypadkach w literaturze ormiańskiej napotykamy na określenia o ,gadaniu starych kobiet” (araspelk' paravanc') o niestereotypowej konotacji ${ }^{4}$, a co za tym idzie, na takie sformułowania, które dla badacza starożytnego antyku chrześcijańskiego wydają się być interesujące z uwagi na treść, jaką niosa.

W literaturze w ogóle, nie tylko w antyku, wyrażenie ,gadania starych kobiet" niesie ze sobą raczej treść pejoratywną. Już św. Paweł zachęcał

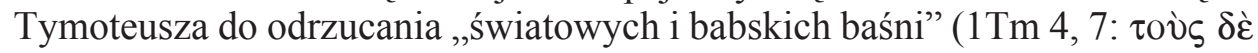

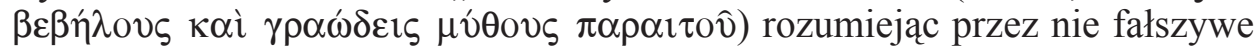
nauki. Obok plotkarskiego bowiem charakteru i mającego w podtekście mówienie o innych na pograniczu obmowy i oszczerstwa, bajanie starych kobiet nie jest czymś wzbudzającym zaufanie, co do źródła, jak i stopnia prawdziwości informacji. Ta kategoria oznacza raczej coś niepewnego lub w najlepszym wypadku sugeruje informacje niesprawdzone, pochodzące ze źródła, któremu trudno nadać jakikolwiek autorytet. Złośliwe obmowy, wtrącanie się w nieswoje sprawy, zajmowanie się rzeczami, o których nie ma się pojęcia, powtarzanie plotek i sensacji, to najczęstsze skojarzenia i konotacje, w których pojawia się określenie o „gadaniu starych kobiet”. Zreszta, takie zabarwienie mogło mieć to sformułowanie także w tekstach kronik armeńskich, biorąc pod uwagę odnotowaną na przykład wypowiedź o plotkach mających utrudnić życie rodu Bagratuni, a wywodzących go od żydowskich protoplastów ${ }^{5}$. W tym kontekście ,gadanie starych kobiet” pojawia się w sytuacji typowej dla ówczesnego toposu literackiego. Oto w sytuacji rozgrywek politycznych dobry bohater musi się zmierzyć z bezimienną plotką, która ma na celu poderwać do niego zaufanie i wzniecić niechęć wśród ludzi. W tej sytuacji ,gadanie starych kobiet" jako przedłużenie oszczerstwa i świadome antagonizowanie ma w sobie wpisane nie tylko fałsz interpretacyjny, ale co istotniejsze i surowsze w ocenie, złą wolę powtarzających te niesprawdzone dane. Stare kobiety, jeśli nawet część $\mathrm{z}$ nich niechcący, to tym niemniej w sposób karygodny powtarzając rozpuszczane złośliwe informacje, odegrały złą rolę w historii kraju.

\footnotetext{
${ }^{4}$ Por. m.in. Lazarus Parpecinus, Historia Armeniae II 27, 51; zob. wyżej n. 3.

${ }^{5}$ Por. Moyses Chorensis, Historia Armeniae I 22, transl. R.W. Thomson: Moses Khorenats'i, History of the Armenians, London 2006; Bais, La vecchiaia nella letteratura armena antica, s. 736-737.
} 
Wydawałoby się więc, że ich ,gadanie" nie ma w sobie nic dobrego, a ocena nie odbiega od obiegowych opinii, jakie były rozpowszechnione w tej epoce. Nie jest to jednak do końca prawdą.

Dokładna analiza prowadzi bowiem do konstatacji, że także w tej sytuacji jest jeden wymiar tych „plotek”, który nie tylko jest interesujący, ale w świadomości zbiorowej nie ma negatywnych konotacji. Otóż „stare kobiety” są dla środowiska armeńskich notabli, jak i całego armeńskiego społeczeństwa tymi osobami, które przechowują „zbiorową pamięć narodu”, czyli są przekaźnikami, a nawet strażniczkami przekazywanych ustnie wielu wydarzeń historycznych. Innymi słowy, to co szczególnie ważne, co poprzez upływ lat odchodzi w niepamięć, może przetrwać właśnie w tym „bajaniu” kobiet. Pochwała ich starości jest wiec związana z koncepcją, w której to właśnie starsze pokolenie jest odpowiedzialne za historię, za pamięć o początkach, a więc w dużym stopniu za to, co nazywamy samoświadomością i samookreśleniem się narodu.

I rzeczywiście, w literaturze ormiańskiej wyraźnie widać to zadanie starszego pokolenia - starych kobiet. To one są tymi, w których opowiadaniach możemy odnaleźć ślady Armenii przedchrześcijańskiej, jak w opowiadaniu o Artawadzie i jego kajdanach ${ }^{6}$. Wydarzenia z dawnych lat, wydarzenia niespisanie, żyją w opowiadaniach starych kobiet. Pełnią więc one funkcję „kolektywnego strażnika tradycji”. Strażnika posługującego się pieśnią, opowiadaniem, ale strażnika czynnego i żywego. Ten ich aktywny udział nie polega na zmianie formy lub treści informacji odnoszących się do dawnych dziejów narodu. Poprzez wpływ na nowe pokolenie, poprzez opiekę nad dziećmi, to właśnie „stare kobiety” są odpowiedzialne za przekaz tego, co ulotne, a co przecież samo w sobie konstytuuje jeden z istotnych kolektywnych elementów tożsamości narodu. Samo spotkanie starszych kobiet i ich obecność, mają więc nie tylko wymiar spotkania towarzyskiego, ale służą czemuś więcej. Innymi słowy, warto strzec relacji „starych kobiet”, gdyż pozwalają one zachować pamięć o konstytutywnych elementach tożsamości społeczeństwa. Nie jest to głos oficjalny, bo mogą się mylić, jak zaznacza kronikarz piszący o początkach rodu Bagratuni ${ }^{7}$, ale jest to przekaz ważny i cenny, stąd też szacunek im okazany, jest jednocześnie szacunkiem okazanym narodowi i całej społeczności armeńskiej. Ich opieka nad dziećmi ma więc także wymiar edukacyjny, związany z czymś, co my dziś nazwalibyśmy wychowaniem patriotycznym, wychowaniem w szacunku i dumie z określonej przynależności narodowej. Dokonuje się to w większym stopniu właśnie poprzez to „bajanie” niż przez zaplanowane programy formacyjne. Na tym etapie rola starych kobiet, bę-

${ }^{6}$ Por. Moyses Chorensis, Historia Armeniae II 61; zob. F. Feydit, L'épopée populaire armenienne, „Bazmavep” 115 (1957) 36-37. O stosunku Mojżesza Choreńskiego do ,gadania starych kobiet”, zob. G. Traina, Materiali per un commento a Movses Xorenac'i, Patmut'iwn Hayoc“ II, „Le Muséon" 108 (1995) 102-103.

${ }^{7}$ Por. Por. Moyses Chorensis, Historia Armeniae II 24. 
dących jednocześnie opiekunkami dzieci jak i strażniczkami pamięci i dumy narodowej, jest niezastapiona dla narodu. Pisał już o tym Platon przypisując ważną rolę wychowawczą mitom i baśniom opowiadanym dzieciom przez niańki i matki ${ }^{8}$. Dodajmy, może ta rola jest tym ważniejsza, im bardziej dana społeczność podlega różnym wpływom. Staje się szczególnie ważna, gdy naród traci własną państwowość, gdy działania sił politycznych zmierzają do zniszczenia tożsamości i odrębności, jak to właśnie miało miejsce w wypadku narodu ormiańskiego.

Jedno z wydarzeń przytoczonych przez autora opracowania M. Baisa uprawdopodabnia tę tezę ${ }^{9}$. Jest to pewien epizod z historii Armenii jako królestwa. Chodzi o oskarżenie króla Tirith przez wdowę P'aranjem o otrucie męża ${ }^{10}$. Istotną rolę w publicznym oskarżeniu króla odgrywa „chór” starych kobiet, powtarzający plotkę - pogłoskę - wieść o odpowiedzialności władcy i nawiązujący do innych wydarzeń, równie niegodziwych, a mających swoje odpowiedniki w historii. Oskarżenie jest skuteczne, a postawa „starych kobiet", które przechowały ważną dla narodu wcześniejszą wiedzę i umiały ją we właściwym czasie i we właściwym miejscu głosić, ma wyraźnie pozytywny osąd. Innymi słowy „opowiadania starych kobiet” przekazały wiedzę ważną dla mędrców, a postawa kobiet, nacechowana odwagą i godnością, budziła zawsze szacunek do starości. Wbrew woli władcy, wbrew układom politycznym, to one stały się strażniczkami prawdy.

W tym samym nurcie jest inna cecha, z jaką starość pojawia się w literaturze starożytnej Armenii; jest nią łączność między dziećmi i starcami ${ }^{11}$. Obie te grupy łączy wiele podobieństw. W armeńskich kronikach występują razem, jako te grupy ludności, które są w szczególny sposób narażone na słabość i wymagają opieki innych. To zestawienie jest nadal kontynuowane: dzieci są przyszłością społeczeństwa, a starzy jego bogactwem. Młodzi mają zadbać o jutro Armenii, ale bez doświadczenia starych i siwowłosych, nic z tego nie wyjdzie. Młodzi symbolizują jak zawsze, przyszłość, ale starzy, jako strażnicy przeszłości, są jednocześnie tymi, którzy gwarantują solidne fundamenty tej przyszłości. Mężczyźni i kobiety opiekują się nimi, bo w nich widzą skarb narodu. Nie w pomnikach, nie w miastach i nie w terytorium. Doszło to do głosu szczególnie wtedy, gdy sasanidzcy władcy imperium paryjskiego postanowili wymóc na Armeńczykach porzucenie chrześcijaństwa i przejście na zoroastrianizm. Elisze Vardapet (410-475) opisuje w swojej Historii Królestwa Varadan i jego

${ }^{8}$ Por. Plato, Respublica II 337c; M. Massaro, Aniles fabellae, „Studi Italiani di Filologia Classica” 49 (1977) 104-135; M. Ibarra Benlloch, Mulier fortis. La mujer en las fuentes cristianas (280-313), Zaragoza 1990, 78-79.

${ }^{9}$ Por. Bais, La vecchiaia nella letteratura armena antica, s. 735.

${ }^{10}$ Por. Faustus Byzantinus, Historiae, ed. G. Uluhogian, trad. M. Bais - L.D. Nocetti: P'awstos Buzand, Storia degli armeni, Milano 1997, 17-18; N. Garsoian, The Epic histories attributed to P'awstos Buzand, Cambridge Mass. 1989, 283, n. 1 i 285, n. 30 i 33.

${ }^{11}$ Por. Bais, La vecchiaia nella letteratura armena antica, s. 743-744 (Vecchiaia e giovinezza). 
wojny z Persami ${ }^{12}$, że naród chroniąc swoją suwerenność, przygotowywał się do odwrotu i ucieczki, ale chronił najpierw starców i dzieci. Trzeba dodać, że zarówno wśród dzieci, jak i wśród starszych, nie ma rozróżnienia na płeć: zarówno chłopcy jak i dziewczęta, starzy mężczyźni, jak i stare kobiety występują razem; wiążą ich ze sobą te same wartości. Starsze pokolenie jako wychowawcy młodego są tymi, którzy gwarantują ciągłość przekazu tradycji. Dzięki nim jest zachowana pamięć o własnej historii. Nie chodzi tu o pamięć na zasadzie dat i wydarzeń, lecz o pamięć na zasadzie poczucia tożsamości narodowej: w tym zakresie wpływ ludzi starszych jest niezastapiony.

W zbiorowym ujęciu dzieci i starców widać też jeszcze jeden aspekt, który czyni starość tak ważną i cenną dla kolejnych pokoleń: starzy przechowują mądrość doświadczenia ${ }^{13}$. Oni stawali przed wieloma wyborami, w ich pamięci są przechowywane zdarzenia z poprzednich pokoleń. Jeśli więc historia jest nauczycielką życia i mistrzynią dla mężów stanu w każdym narodzie i w każdym czasie, to strażnikami tak pojętej historii są ludzie starsi. To poprzez ich pamięć i słowa wydarzenia przeszłe mogą kształtować teraźniejszość, umożliwiając unikanie popełnionych błędów. Starzy ludzie są dla młodych pomocą, by nie powtórzyć błędów przodków, i jednocześnie, by zachować to, co z ich dorobku jest dla wszystkich najcenniejsze. Warto więc nawet w chwilach klęski ich strzec i pielęgnować, bo ich obecność i świadectwo, jakie składają, obok życia dzieci pozwalają nie tylko na to, by zachować fizycznie istnienie kolejnych pokoleń, ale także ocalić istnienie narodu jako społeczności, która bez pamięci zbiorowej się dezintegruje. Innymi słowy, naród z ciałem i duchem to nie tylko naród silny dziećmi (fizyczna przyszłość), ale także mocny historią swoich ludzi starszych.

Inne zagadnienia sygnalizowane w przytaczanym wyżej opracowaniu, to szacunek dla siwizny, ale jako znaku mądrości i doświadczenia, a nie oznace nadchodzącej starczej słabości, co nie jest niczym nowym. Rola, jaką starcy odgrywają w armeńskich rodach, a więc funkcja nahapeta (tanutera) w naxarar, nie jest niczym dziwnym i przypomina rolę pater familias w wielkich rodach rzymskich czy greckich. Podobne odnoszenie się do „starszych” w Kościele też nie budzi zdziwienia. Autor opracowania podkreśla, że nawet w określeniu kapłana przechowano greckie słowo „starszy” (erec'). Wyjątki od reguły, zarówno w życiu cywilnym, jak i we wspólnocie religijnej są możliwe, gdy młody kandydat ma mądrość i dojrzałość starca. Te bowiem dwie cechy są łączone ze starością i stanowią szczególny element godności, jak i motyw szacunku. Takie zresztą podejście znamy z literatury antycznej wszystkich

${ }^{12}$ Por. Eliseus Vardapetus, Historia Vardani et bellum Armaenum VI 124, trad. R. Thomson: Elishē, History of Vardan and the Armenian War, Cambridge Mass. 1982, lub ed. V. Langlois: Élisée Vartabed, Histoire de Vartan et de la guerre des Arméniens, w: tenże, Collection des historiens anciens et modernes de l'Arménie, t. 2, Paris 1869, lub wersja online: http://remacle.org/bloodwolf/ historiens/elisee/vartan.htm.

${ }^{13}$ Por. Bais, La vecchiaia nella letteratura armena antica, s. 737-740 (Vecchi saggi). 
kręgów kulturowych. Może jedno jest ciekawe: starzec w mądrości powinien władać i decydować. Realizm każe jednak widzieć także słabość starca, stąd akcent na to, by zarówno w rodzie, jak i w kraju, władzę wojskową sprawował ktoś młody. Ten realizm, choć z wyraźną dumą nawiązujący do postaci silnych starców, zdolnych wbrew swemu wiekowi sprostać wysiłkom, jakie zniechęcały młodych, zwraca uwagę na kwestie przykładu i autorytetu, także tego fizycznego, jaki powinien cechować dowódcę wojsk. Nie sama wiedza o taktyce, nie sam stopień wojskowy, ale także, a może przede wszystkim, własna sprawność i własna zdolność do udziału w walce, są najbardziej pożądanymi cechami dowódcy. Nie wydaje się to być w sprzeczności ze wspomnianym wyżej walorem roli starców w przechowywaniu pamięci o historii pojętej jako nauczycielki życia. Na tym polu, to właśnie ludzie starsi są autorytetami, których doświadczenie i przeżyte zwycięskie próby, pozwalają na przewodzenie innym.

Ocena starości w literaturze ormiańskiej nie wyróżnia się na tle literatury patrystycznej tamtego okresu. Zasygnalizowana jako novum ocena ,gadania starych kobiet”, czy też podobieństwo między dziećmi i ludźmi starszymi, umiejscawiające ich jako najważniejszych w społeczeństwie dla ratowania jego przyszłości, jest raczej aspektem postawy charakterystycznej dla tamtej epoki, w której ceniono ludzi starszych za ich mądrość i doświadczenie. Rola, jaką odgrywa starsze pokolenie w wychowaniu, każe też inaczej spojrzeć na nasze czasy, w których ciagłość pokoleń, jak i ciagłość przekazu w wielu rodzinach praktycznie nie istnieją, bo funkcję starszych przejęła szkoła i programy edukacyjne, co jak wiemy, nie zawsze jest korzystne dla samych wychowywanych.

\section{OLD AGE IN ARMENIAN PATRISTIC LITERATURE}

\section{(Summary)}

In Armenian tradition, old age, with its grey hair, symbolizes wisdom and responsibility. The country's tradition depends on elderly people. Opinions expressed in the Armenian literature of that time are similar to the ones regarding the same issue occurring in the entire Middle East. Only two issues arising interest and cause surprise. The first thought concerns the gossiping of elderly women, which does not mean anything wrong, but may rather be related to method of transferring tradition that creates collective memory of a nation. The second question is close relation between old age and adolescence. Both children and elderly people are the basic groups in the community on whose survival the nation's future depends. 